\title{
MARKET OVERREACTION PADA BURSA EFEK INDONESIA DENGAN SIZE EFFECT SEBAGAI VARIABEL PEMODERASI
}

\author{
Melisa Tanady, Sukmawati Sukamulja** \\ Universitas Atma Jaya Yogyakarta, Indonesia
}

\begin{abstract}
The purpose of this study is to examine market overreaction phenomenon and market overreaction impact on abnormal return that moderated by size effect of LQ45 index between five years period (2015-2019). Secondary data on Indonesian Stock Exchange website are taken as samples. Wilcoxon test and interaction effects regression test are used to prove the evidences. The Wilcoxon test is developed in order to confirm that market overreaction occurs on winner and loser portfolio. The result shows that market overreaction occurs in the short and long term. Interaction effects regression test shows the size effect as moderating variable does not strengthen or weaken the relationship of market overreaction to abnormal returns. The findings show that company size has an independent effect, which means abnormal returns are more common in large companies. Size effect concept does not occur in the Indonesia Stock Exchange, especially the firms that always in the LQ45 index during the period of research.
\end{abstract}

JEL: G41

Keywords: market overreaction, abnormal return, size effect, winner and loser portfolio

\begin{abstract}
ABSTRAK
Penelitian ini bertujuan untuk menelaah fenomena market overreaction dan pengaruh market overreaction terhadap abnormal return, dimoderasi oleh size effect pada LQ45 tahun 2015 sampai tahun 2019. Data dalam penelitian ini adalah data sekunder yang diambil dari website Bursa Efek Indonesia. Alat uji yang dipakai dalam penelitian ini adalah uji Wilcoxon dan uji regresi interaction effects. Uji Wilcoxon digunakan untuk menguji fenomena market overreaction menunjukkan bahwa market overreaction terjadi pada portofolio winner maupun portfolio loser. Hasil menunjukkan bahwa market overreaction terjadi dalam jangka pendek maupun jangka panjang. Uji regresi interaction effects menunjukkan bahwa size effect sebagai variabel moderasi tidak memperkuat atau memperlemah hubungan market overreaction terhadap abnormal return. Hasil temuan menunjukkan bahwa ukuran perusahaan berpengaruh secara independen, yang berarti abnormal return lebih sering terjadi pada perusahaan besar. Konsep size effect tidak terjadi di Bursa Efek Indonesia terutama pada saham yang secara konsisten berada dalam indeks LQ45 selama periode penelitian.
\end{abstract}

Kata Kunci: reaksi berlebihan, return tidak normal, ukuran perusahaan, portofolio winner dan loser.

\section{PENDAHULUAN}

Komponen yang penting dalam pasar keuangan adalah bagaimana melakukan ekspektasi. Ekspektasi investor dipengaruhi oleh general belief dan specific belief. General belief dipengaruhi oleh hal-hal yang 'umum' diyakini oleh kebanyakan orang. Sebaliknya, specific belief dipengaruhi oleh keyakinan yang berlebih (overconfidence), optimistik dan harapan yang melambung tinggi, ketakutan yang ekstrim, dan pemikiran konservatif. Investor yang tidak rasional mempunyai keyakinan yang berlebihan dalam membeli saham dari perusahaan dengan perkembangan tinggi (high growth stock). Investor merasa senang dan bangga dengan memiliki saham yang mempunyai perkembangan tinggi. Dalam kenyataannya, saham tersebut tidak menjamin untuk mendapatkan return tinggi dimasa depan.

\footnotetext{
*Email : sukmawati.sukamulya@uajy.ac.id

Received : 15-05-2020, Accepted : 26-12-2020, Published : 28-12-2020

P-ISSN : 2087-9954, E-ISSN : 2550-0066. DOI : http://dx.doi.org/10.26418/jebik.v9vi3.40833
} 
Salah satu fenomena pasar modal tidak efisien adalah adanya anomali pasar, yaitu pasar bereaksi secara berlebihan menanggapi suatu berita. Asumsinya, harga semua sekuritas yang diperdagangkan telah mencerminkan semua informasi yang tersedia karena investor berfikir rasional dalam mengambil keputusan atas informasi yang tersedia. Kenyataannya investor sering menunjukkan sikap tidak rasional. Anomali yang berhubungan dengan sikap para investor dalam menanggapi berita adalah market overreaction.

Overreaction terjadi karena adanya return abnormal pada distribusi harga akibat adanya suatu berita, baik berita buruk maupun berita baik. Melalui pengujian secara statik dengan menggunakan 2 buah indeks dan beberapa saham blue chips, dibuktikan bahwa overrection terjadi pada pasar modal Ukraina (Plastun et al., 2018). Selain penelitian overreaction secara statik, pembuktian secara statik dan dinamik juga dilakukan untuk meneliti frekuensi harga overreaction dengan statistik parametrik dan non parametrik (Caporale \& Plastun, 2019a). Fenomena overreaction juga terjadi pada industri real estate. Menggunakan data REIT ditemukan bahwa investor institusional dan investor pasif bereaksi berlebihan pada pasar real estate (Liu \& Lu, 2020). Dari hasil penelitian-penelitian overreaction tersebut terlihat bahwa para investor tidak selalu berfikir secara rasional melalui semua informasi yang tersedia. Fenomena overreaction tidak akan terjadi pada investor yang berfikir secara rasional.

Maraknya inovasi keuangan khususnya cryptocurrency, menyebabkan pengujian overreaction juga diterapkan pada pasar bitcoin. Fluktuasi dan frekuensi harga overreaction juga terjadi pada bitcoin ( Caporale, Plastun, \& Oliinyk, 2019b). Penelitian Caporale et al. (2019b) sejalan dengan penemuan Aggarwal, (2019) dan Urquhart, (2016), bahwa pasar bitcoin merupakan pasar yang tidak efisien. Artinya, pada pasar yang tidak efisien terbukti muncul fenomena overreaction.

Pengaruh size telah terbukti mempengaruhi return pada pasar saham, return semakin rendah sejalan dengan makin rendahnya size (Pandey \& Sehgal, 2016; Miralles-Quiros, MirallesQuiros, \& Gonçalves, 2017). Penelitian overreaction dengan menambahkan pengaruh size dilakukan oleh Chaouachi \& Douagi, (2014) di bursa saham Tunisia dan di pasar India oleh Balakrishnan, (2016). Kedua penelitian tersebut menghasilkan pengaruh size sejalan dengan menghilangnya fenomena overreaction di Tunisia dan India. Indonesia sebagai pasar modal yang menarik bagi investor karena memberikan return yang tinggi (Sukamulja, 2017), perlu untuk diuji anomali pasar yang menyebabkan fenomena overreaction.

Penelitian ini bertujuan untuk meneliti fenomena overreaction dengan melihat pengaruh size sebagai variabel moderasi yang diterapkan pada perusahaan dengan kategori winner dan loser. Perbedaan penelitian ini dengan penelitian sebelumnya karena adanya pembedaan pada kriteria kelompok saham winner dan loser pada kelompok saham LQ45. Portofolio winner adalah sahamsaham yang memiliki kinerja yang baik yang dibuktikan dengan return yang positif. Portofolio loser adalah saham-saham yang memiliki kinerja kurang baik yang dibuktikan dengan return yang negatif. Selain itu, penelitian ini berbeda dengan penelitian sebelumnya karena size effect yang digunakan pada penelitian ini menggunakan pendekatan pasar (kapitalisasi pasar), penelitian sebelumnya menggunakan pendekatan nilai buku (aset total). Pendekatan pasar lebih mencerminkan kondisi nyata saat ini sehingga akan lebih memberikan kontribusi bagi penelitian disektor keuangan karena bersifat forward looking. 
Salah satu faktor yang diduga menjadi penyebab market overreaction adalah anomali size effect. Size effect ini terjadi dikarenakan para investor memutuskan memilih untuk membeli suatu saham berdasarkan ukuran perusahaannya. Pada penelitian klasik yang dilakukan Zarowin, (1990) menyimpulkan bahwa market overreaction adalah bentuk lain dari size effect. Penelitian tersebut juga menyatakan bahwa size effect hanya berlaku pada perusahaan-perusahaan berskala kecil dan efisiensi pasar hanya terjadi pada perusahaan-perusahaan berskala besar.

Dalam penelitian ini, peneliti menggunakan indeks LQ45 sebagai objek penelitian. Pemilihan indeks LQ45 sebagai objek penelitian dikarenakan saham-saham yang terdapat di LQ45 adalah saham dari perusahaan yang memiliki kapitalisasi pasar yang besar, likuiditas yang tinggi. Alasan lainnya adalah indeks LQ45 diketahui sebagai indeks utama yang menggerakkan IHSG, sehingga bisa menjadi cerminan dari kondisi pasar modal di Indonesia.

\section{KAJIAN LITERATUR}

\subsection{Market overreaction}

Konsep market overreaction berasal dari model psikologi (Griffin \& Tversky, 1992). Barberis et al., (2005) mengadaptasi model tersebut untuk menjelaskannya ke dalam perilaku harga pasar dan dikatakan bahwa orang cenderung terlalu percaya diri ketika adanya sinyal yang kuat disertai dengan validitas berita yang rendah. Reaksi berlebihan yang terjadi di pasar yang akan menyebabkan terjadinya return tidak normal (abnormal return). Return tidak normal merupakan kelebihan dari return yang terjadi sesungguhnya di pasar. Return normal merupakan return ekspektasi. Artinya, return tidak normal adalah selisih antara return sesungguhnya dengan return di pasar.

Daniel, Hirshleifer, \& Subrahmanyam (1998) membentuk model perilaku, disebut model Daniel-Hirshleifer-Subramanyam (DHS) menjelaskan bagaimana judgment biases dari investor dapat menyebabkan reaksi berlebih (overreaction) pada beberapa peristiwa dan underreaction pada peristiwa lainnya. Dalam model ini investor dibagi ke dalam dua kategori, yaitu investor yang mempunyai informasi memadai dan investor yang tidak mempunyai informasi yang memadai. Investor yang tidak mempunyai cukup informasi tidak menimbulkan judgment biases karena tidak akan menentukan harga. Kebalikannya, investor yang mempunyai informasi cukup akan melakukan bias, yaitu keyakinan yang berlebih (overconfidence) dan bias self-attribution. Keyakinan yang berlebih menuntun investor untuk menilai sinyal dari informasi privat yang dimiliki terlalu berlebihan dan mempengaruhi harga saham lebih tinggi daripada harga saham yang seharusnya (overvalued). Bias self-attribution menyebabkan penilaian terhadap sinyal dari informasi publik yang dimilikinya terlalu diremehkan, terutama jika sinyal informasi pubik berbeda dengan sinyal informasi privat yang dimiliki. Overreaction terhadap informasi privat dan underreaction terhadap informasi publik cenderung menyebabkan adanya kontinyuitas jangka pendek atas return saham. Dalam jangka panjang akan terjadi sebaliknya, yaitu informasi publik akan menyebabkan bias lebih besar (Sukamulja, 2004).

Investor cenderung terlalu percaya diri terhadap informasi pribadi (private information), yang kemudian sikap terlalu percaya diri ini menyebabkan reaksi berlebihan (overreaction). Harga akan naik maupun turun melebihi perubahan yang terjadi di pasar ketika investor memutuskan untuk membeli atau menjual suatu saham akibat dari kebocoran informasi sebelum adanya 
pengumuman publik. Harga saham yang naik melebihi harga pasar tersebut akhirnya terkoreksi ketika informasi publik diumumkan (Daniel et al., 1998)

Penelitian klasik Bondt \& Thaler, (1985), menyebutkan bahwa fenomena overreaction diukur dari adanya deviasi harga aset dari nilai rata-ratanya sepanjang periode tertentu. Reaksi pasar berlebih banyak terjadi pada pasar modal tidak efisien, khususnya pada pasar modal berkembang. Penelitian overreaction terbukti signifikan terjadi pada pasar modal berkembang dan tidak efisien, misal Santosa \& Santoso, (2019), Plastun et al., (2018); Tripathi \& Aggarwal, (2015) dan Chaouachi \& Douagi, (2014). Penelitian overreaction tetap menarik untuk diteliti agar dapat diperoleh hasil yang konsisten dari waktu kewaktu (robust), seperti penelitian terkini di Ukraina menghubungkan overreaction dengan struktur pasar mikro melalui momentum dan dampak contrarian (Plastun et al., 2020). Dampak contrarian terjadi karena return kelompok saham-saham dari perusahaan kecil mengalahkan return kelompok saham-saham dari perusahaan besar.

Indonesia sebagai salah satu pasar modal berkembang yang menarik bagi investor karena memberikan return yang tinggi, perlu diuji fenomena overreaction. Penelitian Musnadi et al., (2018) menunjukkan bahwa terdapat market overreaction dalam indeks sektoral (9 sektor) dalam periode tahun 2009-2012. Penelitian ini membuktikan bahwa portofolio winner menunjukkan adanya market overreaction, di seluruh indeks sektoral. Sebaliknya, pada portofolio loser, market overreaction hanya terjadi pada sektor industri dasar dan kimia. Hasil dari penelitian ini menyarankan strategi kontrarian sebagai strategi terbaik bagi investor untuk meminimalkan risiko dalam indeks sektoral di pasar saham Indonesia. Octavio \& Lantara, (2014) dengan menggunakan indeks KOMPAS100 selama periode Januari 2010 - Juli 2010, menyimpulkan bahwa terdapat anomali market overreaction pada portofolio loser. Dalam penelitian ini juga menunjukkan bahwa ukuran perusahaan (firm size) mempengaruhi abnormal return. Penelitian menunjukkan bahwa kelompok saham-saham dari perusahaan kecil mengalahkan kelompok saham-saham dari perusahaan besar (Octavio \& Lantara, 2014). Dengan demikian, penelitian ini mengajukan hipotesis yang pertama, market overreaction terjadi pada pasar modal di Indonesia.

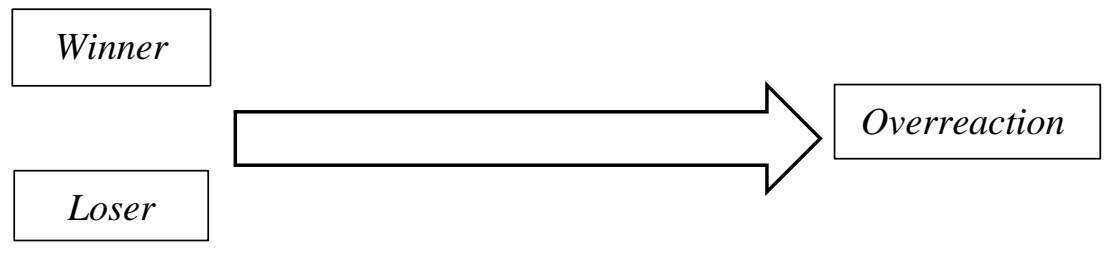

Gambar 1. Hubungan Saham Winner dan Loser Terhadap Overreaction

\subsection{Size Effect pada Market Overreaction}

Anomali size effect pertama kali diperkenalkan oleh Banz, (1981). Anomali size effect merupakan kondisi ketika perusahaan besar memberikan return yang lebih kecil sedangkan perusahaan kecil memberikan return yang lebih besar, sehingga dapat dikatakan bahwa perusahaan kecil berkinerja lebih baik dibandingkan perusahaan besar. Darusman \& Prasetiono, (2012) mengatakan bahwa perusahaan kecil lebih mampu bertahan terhadap goncangan ekonomi yang terjadi karena perusahaan kecil mempertahankan pertumbuhan laba dalam mengontrol usahanya. Dengan perusahaan kecil mempertahankan pertumbuhan labanya sehingga dapat mengurangi hutang, menambah kapasitas produksi, atau membuka cabang baru perusahaan. 
Penelitian size effect terbukti terjadi di pasar India (Pandey \& Sehgal, 2016). Hasil penelitiannya memperlihatkan bahwa pengaruh size telah terbukti mempengaruhi return, return menjadi semakin rendah selaras dengan makin rendahnya size. Miralles-Quiros et al., (2017) membagi sampel ke dalam kelompok perusahaan besar, sedang, dan kecil melalui model multivariate Var-BEKK, membuktikan bahwa harga dan volatilitas dipengaruhi oleh size di pasar modal Brazil. Penelitian overreaction dengan menambahkan pengaruh size dilakukan oleh Chaouachi dan Douagi di bursa saham Tunisia (Chaouachi \& Douagi, 2014) dan di pasar India (Balakrishnan, 2016). Kedua penelitian tersebut menghasilkan pengaruh size sejalan dengan menghilangnya fenomena overreaction di Tunisia dan India. Octavio \& Lantara, (2014) menyimpulkan bahwa abnormal return dipengaruhi oleh ukuran perusahaan. Perusahaan besar memberikan return yang lebih kecil, sebaliknya perusahaan kecil memberikan return yang lebih besar. Dengan demikian, penelitian ini mengajukan hipotesis yang kedua, size effect memoderasi hubungan market overreaction dan abnormal return.

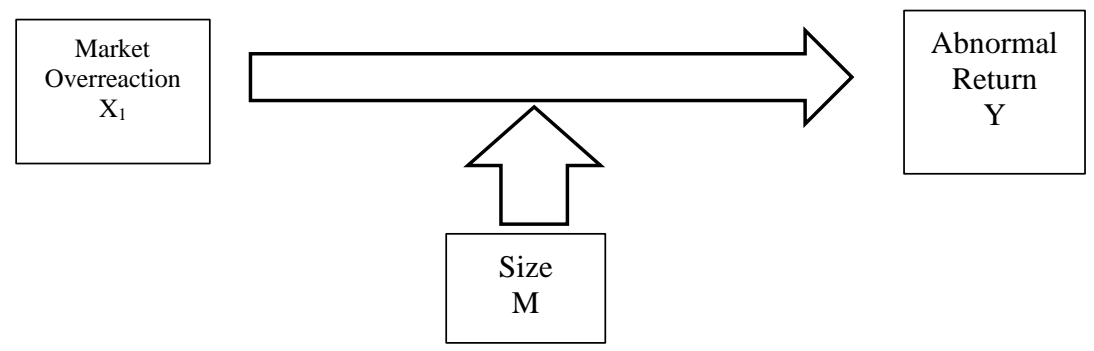

\section{Gambar 2. Pengaruh Market Overreaction terhadap Abnormal Return dengan Size sebagai Variabel Moderasi}

\section{METODE PENELITIAN}

Objek dalam penelitian ini adalah perusahaan yang terdaftar di indeks LQ45 selama periode tahun 2015 sampai 2019, dengan kriteria: (1) Perusahaan yang secara konsisten terdaftar dalam indeks LQ45 periode 2014-2019 (ada 26 saham), (2) Perusahaan yang memiliki informasi mengenai data harga penutupan saham dan jumlah saham beredar, (3) Pembentukan akan dibagi menjadi dua, yaitu portofolio winner dan portofolio loser. Jenis data merupakan data sekunder yang dapat diperoleh pada website resmi IDX, investing.com dan Yahoo! Finance.

Untuk melihat fenomena market overreaction, digunakan perbandingan antara formasi periode dan formasi pengujian. Formasi periode dilakukan 4 bulan pertama dalam periode yang bersangkutan. Formasi pengujian ada dua macam, yaitu formasi pengujian jangka pendek dan formasi pengujian jangka panjang. Formasi pengujian dilakukan pada bulan setelah formasi periode terbentuk. Untuk formasi pengujian jangka pendek terdiri dari 4 bulan, 8 bulan, dan 1 tahun. Untuk formasi pengujian jangka panjang terdiri dari 2,5 tahun, 3,5 tahun, dan 4,5 tahun. Pengujian untuk membandingkan dua sampel yang saling berhubungan digunakan uji Wilcoxon.

Dalam penelitian ini saham dibagi menjadi dua kelompok, yaitu kelompok portofolio loser dan kelompok portofolio winner. Berikut adalah tahapan-tahapan dalam pembentukan portofolio winner dan portofolio loser. Tahapan pertama, menghitung return bulanan dari formasi periode. Tahapan selanjutnya, menghitung cumulative return (CR) dari setiap saham dalam formasi periode. Tahap terakhir, mengurutkan CR dari yang tertinggi ke terendah, 13 saham urutan 
tertinggi akan menjadi portofolio winner dan 13 saham urutan terendah akan menjadi portofolio loser.

Terdapat 3 jenis variabel dalam penelitian ini. Variabel independen adalah market overreaction, variabel dependen adalah abnormal return, dan variabel moderasi adalah size effect. Pengujian abnormal return menggunakan Cumulative Average Abnormal Return (CAAR) yang merupakan penjumlahan dari Average Abnormal Return (AAR) untuk setiap periode. Average abnormal return merupakan hasil rata-rata abnormal return untuk setiap periode, yang dihitung dari selisih return realisasi dengan return indeks LQ45. Periode yang digunakan di sini adalah periode return bulanan. Pengaruh size menggunakan pendekatan nilai pasar bukan nilai buku sehingga digunakan nilai kapitalisasi saham yang selalu masuk dalam LQ45 selama periode penelitian. Berikut adalah pengukuran yang digunakan untuk setiap variabel.

Tabel 1. Pengukuran Variabel

\begin{tabular}{cccl}
\hline $\begin{array}{c}\text { Jenis } \\
\text { Variabel }\end{array}$ & Variabel & \multicolumn{1}{c}{ Pengukuran } & \multicolumn{1}{c}{ Penjelasan } \\
\hline Dependen & $\begin{array}{l}\text { Abnormal } \\
\text { Return }\end{array}$ & CAAR $_{i, t}=\sum_{t=1}^{t} A A R_{i, t}$ & $\begin{array}{l}\text { Akumulasi average } \\
\text { abnormal return } \\
\text { (Santosa \& Santoso, 2019) }\end{array}$ \\
Independen & $\begin{array}{l}\text { Market } \\
\text { Overreaction }\end{array}$ & $A A R_{i, t}=\frac{\sum_{t=1}^{n}\left(R_{i, t}-R_{L Q 45, t}\right)}{n}$ & $\begin{array}{l}\text { Rata-rata tahunan dari } \\
\text { abnormal return bulanan } \\
\text { (Santosa \& Santoso, 2019) }\end{array}$ \\
Moderasi & Size Effect & Market Capitalization \\
$=P_{t} \times J S B$ & $\begin{array}{l}\text { Harga closing saham dikali } \\
\text { jumlah saham beredar dan } \\
\text { dibagi 1 miliar } \\
\text { (Fama \& French, 1995) }\end{array}$ \\
\hline
\end{tabular}

Penelitian dengan variabel moderasi dapat menggunakan analisis regresi interaksi. Untuk melihat efek interaksi pada variable moderasi, ada 3 tahap regresi yang harus dilakukan (Sekaran \& Bougie, 2016). Langkah pertama, akan dilihat hubungan antara market overreaction $\left(\mathrm{X}_{1}\right)$ terhadap abnormal return (Y), dengan model persamaan sebagai berikut:

$$
A R=\beta_{0}+\beta_{1} \text { Overreaction }+\varepsilon_{i} \ldots \ldots \ldots \ldots . . . .
$$

Langkah kedua, pengaruh dari market overreaction $\left(\mathrm{X}_{1}\right)$ terhadap abnormal return $(\mathrm{Y})$ tergantung dari size effect $\left(\mathrm{X}_{2}\right)$ dengan persamaan $\beta_{1}=\gamma_{0}+\gamma_{1}$ Size, sehingga persamaan barunya adalah sebagai berikut:

$$
A R=\beta_{0}+\gamma_{0} \text { Overreaction }+\gamma_{1}(\text { Overreaction } \times \text { Size })+\varepsilon_{i} \ldots
$$

Langkah ketiga, model ini menyatakan bahwa slope dari hubungan antara market overreaction $\left(\mathrm{X}_{1}\right)$ dan abnormal return $(\mathrm{Y})$ dipengaruhi oleh tingkatan dari size effect $\left(\mathrm{X}_{2}\right)$, sehingga dilakukan penambahan variabel Size $\left(\mathrm{X}_{2}\right)$ dalam persamaan ini. Koefisien dalam variabel Size digunakan untuk menentukan apakah variabel moderasi tersebut adalah moderasi murni atau moderasi semu. Model persamaan barunya adalah sebagai berikut:

$$
A R=\beta_{0}+\gamma_{0} \text { Overreaction }+\gamma_{1}(\text { Overreaction } \times \text { Size })+\gamma_{2} \text { Size }+\varepsilon_{i} \ldots \ldots
$$


Notasi:

$\begin{array}{ll}\text { Overreaction } & =\text { Market overreaction yang terjadi di pasar } \\ \text { AR } & =\text { Abnomal return pada periode berjalan } \\ \text { Size } & =\text { Ukuran perusahaan pada periode berjalan } \\ \beta_{1}, \gamma_{0}, \gamma_{1}, \gamma_{2} & =\text { koefisien regresi } \\ \beta_{0} & =\text { konstanta } \\ \varepsilon_{\mathrm{i}} & =\text { residu }\end{array}$

Uji lainnya yang digunakan adalah uji Chow, uji Haussman, uji lagrange multiplier untuk menentukan model regresi terbaik yang akan digunakan. Setelah menentukan model terbaik, maka akan dilakukan uji asumsi klasik, yaitu uji normalitas, multikolinearitas, dan heteroskedastisitas. Untuk implementasi data, uji yang digunakan adalah uji F, uji t, dan uji koefisien determinasi.

\section{HASIL DAN PEMBAHASAN}

Pengujian dikelompokkan pada kelompok portofolio winner dan kelompok portofolio loser. Panel A merupakan hasil portofolio winner dan Panel B merupakan kelompok portofolio loser. Masing-masing kelompok dibagi dalam formasi pengujian jangka pendek ( 4 bulan, 8 bulan, dan 1 tahun), dan formasi pengujian jangka panjang (2,5 tahun, 3,5 tahun, dan 4,5 tahun).

Pengujian dua sampel berpasangan dengan uji Wilcoxon menghasilkan hasil di bawah alpha $1 \%$ yang mengartikan bahwa ada market overreaction dalam portofolio winner maupun portofolio loser baik secara jangka pendek maupun jangka panjang. Pengecualian untuk portofolio loser pada pengujian 4 bulan dengan hasil di bawah aplha $10 \%$.

Tabel 2. Hasil Uji Wilcoxon

\begin{tabular}{|c|c|c|c|c|c|c|}
\hline & $\begin{array}{c}\text { Formasi } \\
\text { Pengujian } \\
4 \text { Bulan }\end{array}$ & $\begin{array}{c}\text { Formasi } \\
\text { Pengujian } \\
8 \text { Bulan }\end{array}$ & $\begin{array}{c}\text { Formasi } \\
\text { Pengujian } \\
1 \text { Tahun }\end{array}$ & $\begin{array}{c}\text { Formasi } \\
\text { Pengujian } \\
2,5 \\
\text { Tahun } \\
\end{array}$ & $\begin{array}{c}\text { Formasi } \\
\text { Pengujian } \\
3,5 \text { Tahun }\end{array}$ & $\begin{array}{l}\text { Formasi } \\
\text { Pengujian } \\
4,5 \text { Tahun }\end{array}$ \\
\hline \multicolumn{7}{|c|}{ Panel A: Portofolio Winner } \\
\hline $\mathrm{Z}$ & $-2,830^{\mathrm{b}}$ & $-2,970^{b}$ & $-2,972^{b}$ & $-3,181^{b}$ & $-3,180^{b}$ & $-3,110^{\mathrm{b}}$ \\
\hline $\begin{array}{l}\text { Asymp. Sig. } \\
\text { (2-tailed) }\end{array}$ & $0,005 * * *$ & $0,003 * * *$ & $0,003 * * *$ & $0,001 * * *$ & $0,001 * * *$ & $0,002 * * *$ \\
\hline \multicolumn{7}{|c|}{ Panel B: Portofolio Loser } \\
\hline $\mathrm{Z}$ & $-1,922^{b}$ & $-2,900^{b}$ & $-3,180^{b}$ & $-3,180^{b}$ & $-3,110^{b}$ & $-3,180^{b}$ \\
\hline $\begin{array}{l}\text { Asymp. Sig. } \\
\text { (2-tailed) }\end{array}$ & $0,055^{*}$ & $0,004 * * *$ & $0,001 * * *$ & $0,001 * * *$ & $0,002 * * *$ & $0,001 * * *$ \\
\hline
\end{tabular}

Panel A memperlihatkan bahwa kelompok portofolio winner pada semua formasi pengujian jangka pendek (4 bulan, 8 bulan, dan 1 tahun) maupun pada pengujian formasi jangka panjang (2,5 tahun, 3,5 tahun, dan 4,5 tahun) signifikan pada $\alpha=1 \%$.

Panel B memperlihatkan kelompok portofolio loser pada pengujian jangka pendek signifikan pada $\alpha=10 \%$ bagi pengujian 4 bulan, dan $\alpha=1 \%$ untuk pengujian 8 bulan dan 1 tahun. Pada formasi pengujian jangka panjang, semuanya signifikan pada $\alpha=1 \%$.

Dari hasil Tabel 2 di atas, dapat disimpulkan bahwa terdapat fenomena overreaction pada kelompok portofolio winner maupun loser pada saham-saham yang konsisten masuk dalam kelompok LQ45 periode 2015-2019, baik dalam jangka pendek maupun jangka panjang. Hipotesis yang menyatakan bahwa market overreaction terjadi pada pasar modal di Indonesia terdukung. 
Hasil ini sejalan dengan penelitian Santosa \& Santoso, (2019), Musnadi et al., (2018) maupun Octavio \& Lantara, (2014).

Untuk pembuktian bahwa size effect memoderasi hubungan market overreaction dan abnormal return, maka dilakukan uji regresi tahap pertama sampai tahap ke tiga. Ketiga hasil uji regresi menunjukkan nilai prob ( $F$-statistic) signifikan lebih kecil dari 0,01 yang berarti bahwa ketiga model regresi ini memenuhi goodness of fit.

Tabel 3. Hasil Uji Regresi Tahap Pertama

\begin{tabular}{|c|c|c|c|c|}
\hline Variable & Coefficient & Std. Error & t-Statistic & Prob. \\
\hline $\mathrm{C}$ & 0,00086 & 0,001743 & 0,493457 & 0,6227 \\
\hline $\begin{array}{l}\text { Overreaction } \\
\left(X_{1}\right)\end{array}$ & 0,511238 & 0,070465 & 7,255188 & $0,000 * * *$ \\
\hline $\begin{array}{l}\text { Adjusted R- } \\
\text { squared }\end{array}$ & 0,659363 & & & \\
\hline Prob(F-statistic) & $0,000 * * *$ & & & \\
\hline
\end{tabular}

Uji t pada regresi tahap pertama dapat dilihat pada nilai prob.t hitung. Nilai prob. pada variabel overreaction, yaitu sebesar 0,0000 . Hasil tersebut dapat diartikan bahwa overreaction sebagai variabel independen berpengaruh secara signifikan positif terhadap abnormal return sebagai variabel dependen. Nilai adjusted $R$-squared pada uji regresi ini menghasilkan nilai sebesar 0,6604 yang berarti bahwa market overreaction terhadap abnormal return memiliki pengaruh sebesar $65,94 \%$ sedangkan sisanya $34,06 \%$ dipengaruhi oleh variabel lainnya.

Tabel 4. Hasil Uji Regresi Tahap Kedua

\begin{tabular}{|c|c|c|c|c|}
\hline Variable & Coefficient & Std. Error & t-Statistic & Prob. \\
\hline $\mathrm{C}$ & 0,000363 & 0,00183 & 0,19897 & 0,843 \\
\hline Overreaction $\left(\mathrm{X}_{1}\right)$ & 0,464665 & 0,08707 & 5,33654 & $0,000 * * *$ \\
\hline $\begin{array}{l}\text { Overreaction*Size } \\
(\mathrm{M})\end{array}$ & 0,001009 & 0,00111 & 0,91197 & 0,364 \\
\hline Adjusted R-squared & 0,658806 & & & \\
\hline Prob(F-statistic) & $0,000 * * *$ & & & \\
\hline
\end{tabular}

Hasil uji t pada variabel overreaction adalah 0,0000 lebih kecil dari 0,01. Hasil uji t pada variabel pemoderasi, yaitu size effect adalah 0,3639 lebih besar dari 0,05. Hasil tersebut menghasilkan kesimpulan bahwa variabel size effect tidak memoderasi hubungan antara market overreaction dan abnormal return. Nilai adjusted $R$-squared pada regresi ini adalah sebesar 0,6588 . Nilai tersebut mengartikan bahwa variabel independen, yaitu overreaction dan variabel moderasi, yaitu size effect memiliki pengaruh sebesar $65,88 \%$. Perubahan adjusted $R$-squared dari 
regresi tahap pertama ke tahap kedua mengalami perubahan yang sangat sedikit, hal ini dikarenakan size effect tidak memoderasi hubungan tersebut. Pernyataan tersebut diperkuat dengan hasil dari $\gamma_{1}$ (koefisien M) sebesar 0,001009 (mendekati 0), yang berarti bahwa variabel size effect bukan variabel moderator.

Tabel 5. Hasil Uji Regresi Tahap Ketiga

\begin{tabular}{lllll}
\hline Variable & Coefficient & Std. Error & t-Statistic & Prob \\
\hline $\mathrm{C}$ & $-0,025777$ & 0,005076 & $-5,078566$ & 0,0000 \\
Overreaction $\left(\mathrm{X}_{1}\right)$ & 0,582211 & 0,079959 & 7,281372 & $0,0000^{* * *}$ \\
Size Effect $\left(\mathrm{X}_{2}\right)$ & 0,000243 & $4,47 \mathrm{E}-05$ & 5,432551 & $0,0000^{* * *}$ \\
$\begin{array}{l}\text { Overreaction*Size } \\
(\mathrm{M})\end{array}$ & $-0,001639$ & 0,001093 & $-1,49919$ & 0,1369 \\
\cline { 3 - 5 }
\end{tabular}

Adjusted R-squared $\quad 0,733345$

Prob(F-statistic) $\quad 0,000 * * *$

***significant at $\alpha=1 \%$, **significant at $\alpha=5 \%$, significant at $\alpha=10 \%$

Menggunakan formula $A R=\beta_{0}+\gamma_{0}$ Overreaction $+\gamma_{1}($ Overreaction $\times$ Size $)+\gamma_{2}$ Size + $\varepsilon_{i}$, nilai probabilitas overreaction $\left(\mathrm{X}_{1}\right)$ tetap signifikan pada $\alpha=1 \%$, size sebagai variabel independen $\left(\mathrm{X}_{2}\right)$ signifikan pada $\alpha=1 \%$, tetapi size tidak signifikan saat menjadi variabel moderasi (M).

Hasil regresi tahap ketiga, nilai prob. pada variabel overreaction $\left(\mathrm{X}_{1}\right)$ sebesar 0,0000 , berarti market overreaction sebagai variabel independen berpengaruh secara signifikan terhadap abnormal return. Uji t pada variabel size effect sebagai variabel moderasi menghasilkan nilai sebesar 0,1369 yang berarti lebih besar dari 0,05. Hal ini berarti size effect tidak signifikan sebagai variabel moderasi $(\mathrm{M})$. Uji t pada variabel size sebagai variabel independen $\left(\mathrm{X}_{2}\right)$ menghasilkan nilai sebesar probabilitas 0,0000 berarti size signifikan pada $\alpha=1 \%$. Size effect sebagai variabel independen berpengaruh terhadap abnormal return. Hipotesis yang menyatakan bahwa size effect memoderasi hubungan market overreaction dan abnormal return tidak terdukung.

Nilai adjusted $R$-square dalam uji regresi ketiga ini adalah 0,7333. Market overreaction dan size effect sebagai variabel independen berpengaruh terhadap abnormal return sebesar $73,33 \%$, sedangkan sisanya $26,67 \%$ dipengaruhi oleh variabel lainnya yang tidak ada di dalam model regresi ini.

Koefisien regresi pada size effect menghasilkan nilai sebesar 0,000243 yang bernilai positif. Nilai positif tersebut artinya adalah semakin besar ukuran perusahaan, maka kemungkinan mengalami abnormal return akan semakin besar. Begitu juga sebaliknya, semakin kecil ukuran perusahaan, maka kemungkinan mengalami abnormal return akan semakin kecil. Hal ini tidak sejalan dengan konsep dari size effect itu sendiri yang mengatakan bahwa perusahaan besar memberikan return yang lebih kecil, dan sebaliknya perusahaan kecil memberikan return yang lebih besar (Banz, 1981).

Hasil penelitian mengenai pengaruh ukuran perusahaan sebagai variabel independen $\left(\mathrm{X}_{2}\right)$ terhadap abnormal return mendukung penelitian Octavio \& Lantara, (2014). Hasil penelitian Octavio \& Lantara, (2014 menyatakan bahwa ukuran perusahaan mempengaruhi abnormal return pada indeks KOMPAS100 periode Januari 2010 sampai Juli 2010. 


\section{SIMPULAN DAN REKOMENDASI}

Berdasarkan pengujian yang telah dilakukan, hasil uji hipotesis pertama didukung, artinya market overreaction terjadi di pasar modal Indonesia. Market overreaction terjadi pada portofolio winner dan portofolio loser baik dalam jangka pendek maupun jangka panjang. Hasil uji hipotesis kedua penelitian tidak didukung, artinya size effect dengan proxy kapitalisasi pasar (M) tidak memoderasi hubungan market overreaction dan abnormal return. Penelitian ini menyimpulkan bahwa ukuran perusahaan sebagai variabel independen $\left(\mathrm{X}_{2}\right)$ memiliki pengaruh terhadap abnormal return. Hasil tersebut menyatakan bahwa semakin besar ukuran perusahaan, maka kemungkinan terjadi abnormal return semakin besar. Ini berarti semakin besar suatu perusahaan, return yang akan diperoleh semakin tinggi. Hal ini tidak sejalan dengan konsep dari size effect itu sendiri, yaitu perusahaan besar memberikan return yang lebih kecil, sedangkan perusahaan kecil memberikan return yang lebih besar (contrarian theory).

Sebagai kesimpulan dari paper ini, investor bertransaksi berdasarkan atas alasan kognitif dan emosi. Investor bertransaksi karena berfikir bahwa investor memiliki informasi cukup yang dibutuhkan. Sewaktu investor tidak mempunyai cukup informasi, transaksi akan membanggakan jika keputusan yang dibuat investor berjalan baik dan sesuai dengan estimasi yang dilakukan, kebalikannya akan menimbulkan penyesalan jika keputusan yang dibuat tidak sesuai dengan harapannya. Odean, (2014) menjelaskan bahwa orang sering melihat keputusan orang lain adalah tidak tepat tetapi melihat keputusannya sendiri sudah tepat dan rasional. Investor sering bertransaksi berdasarkan atas informasi yang diyakini sebagai superior dan relevan, walau dalam kenyataannya tidak demikian dan akan dikoreksi oleh pasar.

Investor dan analis sering mempunyai keyakinan yang berlebih terhadap kemampuannya dan merasa sudah memiliki informasi superior untuk bertransaksi. Investor juga cenderung selalu mengingat kesuksesannya dan tidak pada kegagalannya sehingga investor selalu meningkatkan keyakinannya. Dalam kenyataannya meningkatnya tingkat keyakinan tidak berkorelasi dengan kesuksesan yang dimilikinya. Apakah ini disebut sebagai investor membuat kekeliruan? Menyitir istilah yang digunakan oleh Chen et al., (2001), investor tidak membuat kekeliruan tetapi lebih akurat disebutkan bahwa investor menggunakan tingkatan-tingkatan rasionalitas dalam pengambilan keputusan. Beberapa investor amat rasional sementara lainnya mempunyai keterbatasan akurasi dalam melakukan ekspektasi. Dalam risetnya Hong et al., (2004) mencoba untuk mengerti interaksi sosial dan partisipasi dalam pasar saham melalui investigasinya terhadap belief dan opini investor. Adanya pengaruh psikologi pada pembuatan keputusan keuangan mempengaruhi harga saham yang dipicu oleh belief para investor.

Temuan ini berkesimpulan bahwa para investor berekspektasi lebih pada perusahaan besar. Hal ini mungkin dikarenakan citra perusahaan yang baik di mata publik dan investor lebih percaya untuk berinvestasi pada perusahaan besar.

Penelitian ini tidak membanding perusahaan LQ45 dan non-LQ45, sehingga size sebagai variabel moderasi tidak signifikan, selain itu penelitian ini tidak memasukkan volatilitas pasar pada sesi pagi dan sesi siang perdagangan. Perbandingan sesi pagi dan siang perdagangan dapat memperlihatkan intensitas overreaction pada pasar saham. Perdagangan sesi pagi biasanya informasi belum lengkap terkumulasi dan perdagangan sesi siang informasi sudah lengkap dikumpulkan oleh investor sehingga intensitas overreaction akan dapat dibandingkan. 


\section{DAFTAR PUSTAKA}

Aggarwal, D. (2019). Do bitcoins follow a random walk model? Research in Economics, 73(1), $15-22$.

Balakrishnan, A. (2016). Size, value, and momentum effects in stock returns: Evidence from India. Vision, 20(1), 1-8.

Banz, R. W. (1981). The Relationship Between Return and Market Value of Common Stocks. Journal of Financial Economics, 9, 3-18.

Barberis, N., Shleifer, A., \& Vishny, R. W. (2005). A model of investor sentiment. Advances in Behavioral Finance, 2, 423-459.

Bondt, W. F. M. B, \& Thaler, R. (1985). Does the Stock Market Overreact? The Journal of Finance, 40(3), 793-805.

Caporale, G. M, \& Plastun, A. (2019a). On stock price overreactions: frequency, seasonality and information content. Journal of Applied Economics, 22(1), 602-621.

Caporale, G. M., Plastun, A., \& Oliinyk, V. (2019b). Bitcoin fluctuations and the frequency of price overreactions. Financial Markets and Portfolio Management, 33(2), 109-131.

Chaouachi, O., \& Douagi, F. (2014). Overreaction effect in the Tunisian stock market. Journal of Asian Business Strategy, 4(11), 134-140.

Chen, J., Hong, H., \& Stein, J. C. (2001). Forecasting crashes: Trading volume, past returns, and conditional skewness in stock prices. Journal of Financial Economics, 61(3), 345-381.

Daniel, K., Hirshleifer, D., \& Subrahmanyam, A. (1998). Investor psychology and security market under- and overreactions. Journal of Finance, 53(6), 1839-1885.

Darusman, D., \& Prasetiono. (2012). Analisis Pengaruh Firm Size, Book To Market Ratio, Price Earning Ratio, Dan Momentum Terhadap Return Portofolio Saham, Diponegoro Journal of Management, 1(4), 212-225.

Fama, E. F., \& French, K. R. (1995). Size and Book-to-Market Factors in Earnings and Returns. The Journal of Finance, 50(1), 131-155.

Griffin, D., \& Tversky, A. (1992). The weighing of evidence and the determinants of confidence. Cognitive Psychology, 24(3), 411-435.

Hong, H., Kubik, J. D., \& Stein, J. C. (2004). Social Interaction and Stock-Market Participation. $\operatorname{LIX}(1), 137-163$.

Liu, M. Y., \& Lu, C. (2020). The Continuing Overreaction in the REIT Market. Journal of Real Estate Finance and Economics, 61(1), 129-149.

Miralles-Quiros, M. D. M., Miralles-Quiros, J. L., \& Gonçalves, L. M. (2017). Revisiting the size effect in the Bovespa. RAE Revista de Administracao de Empresas, 57(4), 317-329.

Musnadi, S., Faisal, \& Majid, M. S. A. (2018). Overreaction and underreaction anomalies in the Indonesian stock market: a sectoral analysis. International Journal of Ethics and Systems, 34(4), 442-457.

Octavio, D. Q. \& Lantara, I. W. (2014). Market Overreaction, Size Effect Atau Liquidity Effect? Studi Pada Bursa Efek Indonesia. Jurnal Manajemen, Strategi Bisnis Dan Kewirausahaan, $8(1), 11-17$.

Odean, T. (2014). Are Investors Reluctant to Realize Their Losses? The Journal of Finance, $\operatorname{LIII}(5), 1775-1798$. 
Pandey, A., \& Sehgal, S. (2016). Explaining Size Effect for Indian Stock Market. Asia-Pacific Financial Markets, 23(1), 45-68.

Plastun, A., Makarenko, I., Khomutenko, L., Belinska, Y., \& Domashenko, M. (2018). Exploring frequency of price overreactions in the Ukrainian stock market. Investment Management and Financial Innovations, 15(3), 157-168.

Plastun, A., Strochenko, N., Zhmaylova, O., Sliusareva, L., \& Bashlay, S. (2020). Momentum and contrarian effects in the Ukrainian stock market: Case of daily overreactions. Investment Management and Financial Innovations, 17(1), 24-34.

Santosa, P. W., \& Santoso, P. W. (2019). Does Exchange Rate Volatility cause Overreaction in the Capital Market? Evidence from Indonesia. International Journal of Finance and Accounting, $8(3), 80-87$.

Sekaran, U., \& Bougie, R. (2016). Research Methods for Business: A Skill-Building Approach. Chichester: John Wiley \& Son.

Sukamulja, S. (2004). Irrational Financial Market Behavioral: Evidence from Jakarta Stock Exchange. Empirika, 17(1), 1-19.

Sukamulja, S. (2017). Pengantar Pemodelan Keuangan dan Analisis Pasar Modal. Yogyakarta: BPFE.

Tripathi, V., \& Aggarwal, S. (2015). Prior Return Effect in Indian Stock Market: An Intra-day Analysis. International Journal of Financial Management, 5(1).

Urquhart, A. (2016). The inefficiency of Bitcoin. Economics Letters, 148, 80-82.

Zarowin, P. (1990). Size, Seasonality, and Stock Market Overreaction. The Journal of Financial and Quantitative Analysis, 25(1), 113. 